\title{
Plant defences against mammalian herbivores: are juvenile Acacia more heavily defended than mature trees?
}

\author{
R. BROOKS* and N. OWEN-SMITH*
}

Keywords: Acacia, browsers, defence, tannins, polyphenols, thorns

\section{ABSTRACT}

\begin{abstract}
Juvenile trees are expected to be more heavily defended against browsing mammals than mature plants. Juvenile and mature trees of Acacia tortilis and A. nilotica occurring at Nylsvley, Northern Transvaal, were quantitatively compared in terms of some potential chemical and physical defences. Neither species showed any significant difference between juvenile and mature trees in terms of total polyphenol content, condensed tannin content, protein precipitating ability or protein content in leaves. Both species showed age-class differences in spinescence. In A. nilorica, thorns on branch tips were longer and more closely spaced and leaves were smaller in juveniles than in adults. Hence juveniles of this species appear to be physically more heavily defended than mature plants. In A. tortilis, curved thorns were longer, but straight thoms were shorter than in mature trees. There was no difference between age classes in overall thorn density, but juveniles had a higher curved to straight thom ratio. It is not obvious what the effects of these differences might be on mammalian browsers.
\end{abstract}

\section{UITTREKSEI}

\begin{abstract}
Na verwagting is jong bome beter as volwasse plante teen blaarvretende soogdiere beskerm. Jong en volwasse bome van Acacia tortilis en $A$. nilotica by Nylsvley, Noord-Transval, is kwantitatief vergelyk in terme van etlike potensiële chemiese en fisiese verdedigingsmeganismes. Nie een van die spesies het enige beduidende verskil tussen jong en volwasse bome getoon in terme van totale polifenolinhoud, gekondensoerde tannieninhoud, proteinpresipiteringsvermoe of proteieninhoud in blare nie. Albei spesies het ouderdomsklasverskille in doringagtigheid getoon. By A. nilotica, was dorings op punte van takke langer en digter opmekaar en blare was kleiner by jong bome as by volwassenes. Dit blyk dus dat jong bome van hierdie spesie fisies beter beskerm is as volwasse plante. By A. tortilis, was krom dorings langer, maar reguit dorings was korter as in volwasse bome. Daar was geen verskil in algehele digtheid van dorings tussen ouderdomsklasse nie. maar jong bome het " $\mathrm{n}$ hoër verhouding krom tot reguit dorings gehad. Dit is nie duidelik wat die uitwerkings van hierdie verskille op soogdierblaarvreters is nie.
\end{abstract}

\section{INTRODUCTION}

Woody plants that are browsed by mammals when still juvenile may show retarded growth and increased time to reach reproductive maturity (Bryant et al. 1983; Bryant et al. 199 lb). Hence, woody plant defences against mammalian herbivores could be expected to be expressed more strongly in juveniles than in mature trees (Bryant \& Kuropat 1980): Bryant et al. 1983: Bryant et al. 1991 a, b. c). This has been documented in Alaskan paper birch (Betula resinifera) browsed by snowshoe hare (Lepus (americanus) (Reichardt et al. 1984) and quaking aspen (Populus tremuloides) browsed by beaver (Castor canadensis) (Bascy et al. 1990). The objective of this study was to assess whether some potentially defensive traits were expressed more strongly in juvenile Acacia trees than in mature trees. No studies comparing anti-herbivore defences of juvenile and mature Acacia trees have yet been reported.

Defences can take the form of either chemical compounds or physical structures. Chemical defences include secondary metabolites (Freeland \& Janzen 1974: Bryant \& Kuropat 1980); Cooper \& Owen-Smith 1985; Cooper et al. 1988: Bryant el al. $1991 \mathrm{lc}$ ), high fibre contents (Bell 1983) or low nutrient levels (Lundberg \& Astrom 1990).

\footnotetext{
* Department of Zeology. University of the Witwatersrand. Johannesburg 2050 .

MS. reccived: $1993-(19-(1) 2$.
}

Physical defences include thoms and spines (Cooper \& Owen-Smith 1986; Milewski et al. 1991).

Polyphenols, including condensed and hydrolysable tannins are widespread among woody plant species (Swain 1979) and are commonly implicated as quantitative defences against herbivory (Rhoades \& Cates 1975: Van Hoven 1984: Cooper \& Owen-Smith 1985: Cooper et al. 1988; Teague 1989b; Du Toit et al. 1990; Furstenburg \& Van Hoven in press). A. tortilis trees have low amounts of condensed tannins in their leaves. whereas $A$. nilorica is relatively high in total polyphenol content (Cooper \& Owen-Smith 1985). Both species are relatively palatable to browsing ungulates (Owen-Smith \& Cooper 1987).

There is circumstantial evidence for longer thorns being more effective as defences against browsers than shorter thorns in several Acacia species (Foster \& Dagg 1972; Young 1987: Milewski el al. 1991). Cooper \& Owen-Smith (1986) noted that thorns were more effective in restricting leaf losses to browsers when leaves were small. In Acacia karroo, the rate of intake of browse by goats was positively related to leaf mass per unit length of shoot (Teague 1989a). Thus leaf size and thorniness might act together in defence of trees against browsing ruminants. A. nilotica has paired. straight thorns, while $A$. ortilis has both 'hooked' thorns and straight thorns. 


\section{MATERIALS AND METHODS}

The study area was the Nylsvley Nature Reserve in northern Transvaal, South Africa ( $\left.24^{\circ} 39^{\prime} \mathrm{S}, 28^{\circ} 42^{\prime} \mathrm{E}\right)$. Acacia tortilis and A. nilotica occur in the woodlands flanking the floodplain and in disturbed sites of former human habitation (Coetzee et al. 1976; Cooper \& OwenSmith 1986).

Ten pairs of trees comprising a juvenile and a mature plant no more than $50 \mathrm{~m}$ apart, were sampled for each species. Sampling was restricted to the disturbed Acacia woodland, and samples were paired to control for spatial differences in soil nutrients and browsing pressure. Adult trees were defined as those showing evidence of reproductive maturity (i.e. presence of flowers or seed pods). No trees taller than $1.7 \mathrm{~m}$ were considered for the juvenile class.

All collections took place on two consecutive days in March 1992, because during late summer all leaves are mature but not yet senescent. For each plant, leaves were taken from the terminal $250 \mathrm{~mm}$ of five branches on the northern side of the canopy at a height of between 0.75 and $1.7 \mathrm{~m}$ (within the browsing reach of impala and/or kudu). All leaf collecting took place between $06 \mathrm{~h} 00$ and $09 \mathrm{~h} 00$. Leaves of each pair of juvenile and mature trees were collected consecutively, with no more than 15 minutes between collection for members of any pair, to eliminate the effects of short time-scale fluctuations in leaf chemistry. Analysis of leaf nitrogen content provides a check for differences in leaf age between the juvenile and mature trees sampled.

Collected leaves were placed in plastic bags, and kept in a cooler box with ice blocks until the end of the collecting session (maximum 3 hours). At the end of the session, leaves were frozen in a deep freeze at $-4^{\circ} \mathrm{C}$. They were kept frozen until used for weighing and extraction for chemical analysis.

\section{Physical defences}

The length of all thorns within $250 \mathrm{~mm}$ of the branch tip on the same branches from which leaves were collected was measured to the nearest millimetre. The density of thoms was measured by counting the number of thorns or thorn pairs within $250 \mathrm{~mm}$ of the branch tip.

The frozen leaves from each tree were weighed to the nearest $10 \mathrm{~g}$. From these measurements, the mean fresh leaf mass for each tree was calculated to give an index of leaf size for each tree. The leaf matter used in extraction and for protein analysis (about $2.0 \mathrm{~g}$ ) was weighed out from frozen leaf material. Several leaves were later dried in order to determine the relationship between dry mass and the mass of fresh leaf material so that chemical parameters could be reported in terms of 'percentage of dry mass'.

\section{Chemical analyses}

Phenolics were extracted according to the method described by Hagerman (1977). Approximately $2.0 \mathrm{~g}$ leaf matter was frozen with liquid nitrogen and ground in a mortar. The crushed material was then centrifuged three times at $2500 \mathrm{rpm}$ using $20 \mathrm{ml}$ of $70 \%$ acetone as solvent in each iteration. The supernatant was poured off each time and stored at $4^{\circ} \mathrm{C}$ until needed for chemical analysis.

Condensed tannin content was measured using the acid butanol assay (Porter et al. 1986). The absorbances at 550 $\mathrm{nm}$ were standardised against purified sorghum tannin. The total polyphenol content was determined using the Prussian blue assay (Price \& Butler 1977). Absorbance was read at $720 \mathrm{~nm}$. The standard was commercial tannic acid made up from powder form in the laboratory with $70 \%$ acetone.

The protein precipitating ability of the chemicals in the leaves was determined by means of radial diffusion using the method described by Hagerman (1977). The diameter of the ring of precipitated BSA in an agarose gel was measured, the square of the diameter being proportional to the amount of tannin in the sample (Hagerman 1977).

Protein content was estimated by determining nitrogen content by Kjeldahl oxidation using sulphuric acid and a selenium catalyst (Keeney 1982). The amount of ammonium in the digest was determined colorimetrically following the method of Cataldo et al. (1975) and absorbance was read at $655 \mathrm{~nm}$. The absorbances were compared to a standard curve plotted from the absorbances of dilutions of an ammonium sulphate solution. Crude protein content equals $6.25 \times$ nitrogen concentration.

For each species, each variable was compared by means of a Wilcoxon paired summed-ranks test (Siegel \& Castellan 1989) because it was not possible to confidently assume normality in any of the parameters. The alpha level of acceptance for significant results was 5 percent. Tests were one-tailed tests of the hypothesis that juveniles are more heavily defended than mature trees.

\section{RESULTS}

Heights of juvenile trees sampled (mean and range) were as follows: Acacia nilotica $1.24 \mathrm{~m}(0.89-1.60 \mathrm{~m})$, A. tortilis $1.16 \mathrm{~m}(0.79-1.58 \mathrm{~m})$.

\section{Chemical measures}

The total polyphenol content of leaves of juvenile $A$. nilotica did not differ significantly from that of leaves of the mature plants (Table 1). The protein precipitating ability (as measured by radial diffusion) of the extracts from juvenile and mature $A$. nilotica did not differ significantly, and neither did the protein contents of juvenile and mature plants. A. nilotica did not show any sign of containing condensed tannins, in that the extracts did not turn purple (indicative of condensed tannin) in the acid butanol test.

The polyphenol and condensed tannin contents for juvenile $A$. tortilis trees did not differ significantly from those of mature plants, nor did crude protein content or protein precipitating capacity (Table 1). 
TABLE 1.-Comparative levels of potential chemical defences of juvenile and mature Acacia nilotica and $A$. torilis. $\mathrm{N}=10$ trees

\begin{tabular}{|c|c|c|c|c|c|c|}
\hline & \multirow{2}{*}{\multicolumn{2}{|c|}{$\begin{array}{c}\text { A. nilotica } \\
\text { Mean } \pm \text { S.D. }\end{array}$}} & \multicolumn{4}{|c|}{ A. tortilis } \\
\hline & & & \multirow[t]{2}{*}{ Sig. } & \multicolumn{2}{|c|}{ Mean \pm S.D. } & \multirow[t]{2}{*}{ Sig } \\
\hline & juv. & mat. & & juv. & mat. & \\
\hline Polyphenols* & $10.0 \pm 1.76$ & $93 \pm 1.84$ & n.s. & $0.9 \pm 0.19$ & $1.1 \pm 0.26$ & n.s. \\
\hline Condensed tannin** & 0 & 0 & & $2.39 \pm 0.70$ & $2.37 \pm 0.85$ & n.s. \\
\hline Protein precipitation*** & $5.6 \pm 0.66$ & $5.5 \pm 0.85$ & n.s. - & $4.2 \pm 1.77$ & $5.1 \pm 1.58$ & n.s. \\
\hline Crude protein $(\% \mathrm{~d} \mathrm{~m})$ & $15.3 \pm 1.68$ & $15.6 \pm 2.23$ & n.s. & $14.7 \pm 1.08$ & $14.0 \pm 1.70$ & n.s. \\
\hline
\end{tabular}

* Tannic acid equivalents as a percentage of dry mass; ** Sorghum tannin equivalents as a percentage of dry mass; *** mm diffusion on gel: juv., juvenile; mat., mature; sig., significance.

\section{Physical parameters}

Thorns of juvenile $A$. nilotica were significantly longer $(P=0.042)$ than those of mature trees (Table 2). The thorns of juveniles were, on average one and a half times as densely spaced as those of mature trees due to shorter internode lengths $(P=0.003)$. Leaves of juvenile $A$. nilotica weighed only $75 \%$ of the mass of those of mature trees $(\mathrm{P}=0.003)$.

Comparison of the physical defences of juvenile and mature $A$. tortilis trees was complicated by the fact that this species bears both short. recurved ('hooked" or 'curved") thoms and long. 'straight' thorns. The overall density of thorns on juvenile trees did not differ significantly from that on mature trees (Table 2).

The ratio of straight to curved thorns was significantly higher in juveniles $(P=0.016)$ than in mature plants. Curved thorns were significantly longer on juvenile than on mature trees $(\mathrm{P}=0.003)$, whereas straight thorns were longer on mature trees than on juveniles $(P=0.05)$. Leaf mass did not differ significantly between juveniles and mature trees of this species.

\section{DISCUSSION}

\section{Chemical defence}

The results of this study indicate that for both Acacia nilotica and $A$. tortilis, juvenile plants did not differ from those of adult trees in total polyphenol. condensed tannin or crude protein content. Hence juveniles of these two Acacia species did not appear to be more heavily defended chemically, at least at the time of year when samples were collected. This is in contrast to the findings of Reichardt et al. (1984) with regard to surface resins on twigs of paper birch. This may be related to differences in the way leaves and twigs are defended. Bryant et al. (1992: 345) note that 'In every case that has been studied. the low palatability of the juvenile phase has been related to increased concentrations of antifeedants in intermodes' (our emphasis).

Carbon-based secondary metabolites, such as tannins, would be costly defences during periods of rapid growth such as the juvenile stage (Bryant et al. 1991 b, c, 1992). Juveniles of both of these Acacia species show high intrinsic growth rates (Bryant et al. 1989).

It is also possible that polyphenols, condensed tannins and protein precipitating compounds do not play a defensive role in these species, since Owen-Smith \& Cooper (1987) classed both species as palatable to browsing ruminants. Our results confirm that $A$. tortilis has relatively low concentrations of condensed tannins in leaves, and that $A$. nilotica has high total polyphenol contents, but no measureable condensed tannins, as found by Cooper \& Owen-Smith (1985) and Cooper et al. (1988). Furthermore, our findings indicate that despite having a high polyphenol content. $A$. nilotica leaf extracts have a protein precipitating ability that is scarcely higher than that of $A$. tortilis. This suggests that the polyphenols found in the leaves of $A$. nilotica are mostly not tannins or other protein binding compounds.

\section{Physical defence}

Juvenile $A$. nilotica specimens have significantly longer and more densely spaced thoms and their leaves

TABI.E 2.-Comparison of potential physical defences in juvenile and mature Acacia nilorica and A. (orrilis. $\mathrm{N}=10$ trees

\begin{tabular}{|c|c|c|c|c|c|c|}
\hline & \multirow{2}{*}{\multicolumn{2}{|c|}{$\begin{array}{l}\text { A. nilotica } \\
\text { Mean } \pm \text { S.D. }\end{array}$}} & \multicolumn{4}{|c|}{ A. tornilis } \\
\hline & & & \multirow[t]{2}{*}{ Sig. } & \multicolumn{2}{|c|}{ Mean \pm S.D. } & \multirow[t]{2}{*}{ Sig. } \\
\hline & juv. & mal. & & juv. & mal & \\
\hline Thorn density $\left(m^{-1}\right)$ & $81 \pm 13.5$ & $54 \pm 15.8$ & $0.0(0) 2$ & $8 x \pm 16.1$ & $86 \pm 24.2$ & n.s. \\
\hline $\begin{array}{l}\text { Thorn length (mm) } \\
\text { straight }\end{array}$ & $22.1 \pm 1.23$ & $18.3 \pm 1.12$ & 0.021 & $3.3 \pm 14.8$ & $38 \pm 1.3 .2$ & 0.025 \\
\hline curved & & & & $4.4 \pm 1.7$ & $3.3 \pm 1.2$ & 0.002 \\
\hline Curved : straight thorns & & & & $0.495 \pm 0.21$ & $0.2(19) \pm 0.19$ & 0.008 \\
\hline Frozen leaf mass (g) & $0.33 \pm 0.02$ & $0.46 \pm 0.08$ & 0.0012 & $0.27 \pm 0.03$ & $0.28 \pm 0.03$ & n.s. \\
\hline
\end{tabular}

juv., juvenile; mat., mature; sig., significance. 
are smaller than those of mature trees. Working in the same study area, Cooper \& Owen-Smith (1986) compared scrub $(<1 \mathrm{~m}$ high) and mature trees of this species in terms of thorn length and density. They reported thorn densities of $91 \mathrm{~m}^{-1}$ for scrub and $59 \mathrm{~m}^{-1}$ for trees, which are very similar to those found for juveniles and mature trees respectively in this study. However A. nilotica scrub showed a somewhat shorter mean thom length $(13 \mathrm{~mm})$ than found for juveniles in this study, and trees had longer thorns $(26 \mathrm{~mm})$ on average than mature plants in this study. The juvenile plants sampled in this study were somewhat taller (mean $=1.24 \mathrm{~m}$ ) than the scrub category (all individuals less than $1 \mathrm{~m}$ ) of Cooper \& Owen-Smith. Also, Cooper and Owen-Smith measured thoms over a longer portion of the branch than the terminal $250 \mathrm{~mm}$ used in this study.

Thoms retard mammalian browsing by restricting bite size (Cooper \& Owen-Smith 1986; Teague 1989a), but the relative importance of thorn length and thorn density in defence is not clear. Heavy browsing can induce longer thoms in regrowth than are seen in unbrowsed plants (Foster \& Dagg 1972; Young 1987; Milewski et al. 1991), suggesting that longer thoms might be more effective browsing deterrents. The measurements presented here indicate that juvenile Acacia nilotica are physically better defended than mature trees only if two conditions hold. Firstly, it must be shown that greater thom length and/or density provides better defence against browsers than shorter or less dense thorns. Secondly, the pattern shown by juveniles under one metre in height ( Cooper \& OwenSmith 1986) must be explained. The smaller leaves of juveniles in our study may assist in further restricting feeding rates of browsers.

In $A$. tortilis, curved thorns are less dense but longer, and straight thoms more dense but shorter, in juveniles than in mature trees. Leaf size did not differ between classes. Curved thorns retard biting rates of kudu and impala (Cooper \& Owen-Smith 1986). The longer, less densely spaced curved thoms in the juvenile trees do not necessarily indicate heavier juvenile defence because it is not known how (if at all) the length and density of curved thorns contribute to their effectiveness as defences. Differences in the lengths and relative densities of both thorn types in Acacia tortilis cannot be said to support an hypothesis of heavier juvenile defence until the defensive roles played by the two thom types is properly understood.

\section{ACKNOWLEDGEMENTS}

Dr Mary Scholes provided laboratory facilities and advice regarding laboratory techniques. Wendy Wolhuter and three anonymous reviewers greatly improved this manuscript with their suggestions. The Nature Conservation division of the Transvaal Provincial Administration gave permission to work in and take samples from the Nylsvley Nature Reserve. Gary Marnoweck helped with arrangements at Nylsvley. This study was conducted as a B.Sc. Honours project (RB) and funding and financial support was obtained from the Zoology Department of the University of the Witwatersrand, the Foundation for Research Development and the University of the Witwatersand senior bursary program.
REFERENCES

BASEY, J.M. JENKINS, S.H. \& MILLER, G.C. 1990). Food selection by beavers in relation to inducible defenses of Populus tremuloides. Oikos 59: 57-62.

BELL. R.H.V. 1983. The effect of soil nutrient availability on community structure in African ecosystems. In B.J. Huntley \& B.H. Walker, Ecology of tropical savannas: 193-216. Springer-Verlag, Berlin.

BRYANT, J.P. \& KUROPAT, P.J. 1980. Selection of winter forage by subarctic browsing vertebrates: the role of plant chemistry. Annual Review of Ecology: and Systematics 11: 261-285.

BRYANT, J.P., CHAPIN, F.S. \& KLEIN. D.R. 1983. Carbon/nutrient balance of boreal plants in relation to vertebrate herbivory. Oikos 40): 357-368.

BRYANT, J.P., DANELL, K., PROVENZA, F., REICHARDT, P.B., CLAUSEN, T.A. \& WERNER, R.A. 1991 a. Effects of mammal browsing on the chemistry of deciduous woody plants. In D.W. Tallamy \& M.J. Raupp, Phvtochemical induction by herbivores. Wiley, New York.

BRYANT, J.P.. KUROPAT, P.J., COOPER, S.M., FRISBY, K. \& OWENSMITH. N. 1989. Resource availability hypothesis of plant antiherbivore defence tested in a South African savanna ecosystem. Nature 340: 227, 228

BRYANT, J.P., KUROPAT, P.J., REICHARDT. P.B. \& CLAUSEN, T.P. 199 1b. Controls over the allocation of resources by woody plants to chemical antiherbivore defense. In T.R. Palo \& C.T. Robbins, Plant defenses against mammalian herbivory. CRC Press. Boca Raton.

BRYANT, J.P.. PROVENZA, F.D.. PASTOR, J., REICHARDT, P.B., CLAUSEN. T.P. \& DU TOIT. J.T. 1991c. Interactions between woody plants and browsing mammals mediated by secondary metabolites. Annual Review of Ecology and Systematics 22: $431-4.36$.

BRYANT, J.P.. REICHARDT, P.B.. CLAUSEN. T.P.. PROVENZA, F.D.. KUROPAT. P.J. 1992. Woody plant-mammal interactions. In G.A. Rosenthal \& M.R. Berenbaum. Herbivores: their interactions with secondary plant metabolites, 2nd edn. Vol. 2: evolutionan and ecological processes. Academic Press.

CATALDO. D.A.. HAROON, M., SCHRADER, L.E. \& YOUNGS, V.L. 1975. Rapid colorimetric determination of nitrate in plant tissue by nitration of salicylic acid. In J.M. Anderson \& J.S.I. Ingram 1989. Tropical soil biology and fertility: a handbook of methods. $\mathrm{CAB}$ International. Originally in Communication in Soil Science \& Plant Analysis 6: 71-80.

COETZEE, B.J., VAN DER MEULEN, F., ZWANZIGER. S., GONSALVES. P. \& WEISSER. P.J. 1976. A phytosociological classification of the Nylsvley Nature Reserve. Bothalia 12: 137-160).

COOPER. S.M. \& OWEN-SMITH. N. 1985. Condensed tannins deter feeding by browsing ruminants in a South African savanna. Oecologia 67: 142-146.

COOPER. S.M. \& OWEN-SMITH. N. 1986. Effects of plant spinescence on large mammalian herbivores. Oecologia 68: 446455.

COOPER. S.M., OWEN-SMITH. N. \& BRYANT, J.P. 1988. Foliage acceptability to browsing ruminants in relation to seawonal changes in the leaf chemistry of wordy plants in a South African savanna. Oecologia $75: 336-342$.

DU TOIT. J.T., BRYANT. J.P. \& FRISBY, K 1990. Regrouth and palatability of Acacia shoots following pruning by African savanna browsers. Ecology 71: 149-154.

FOSTER. J.B. \& DAGG, A.I. 1972. Notes on the biology of the giraffe. East African Wildlife Journal 10: 1-16.

FREELAND, W.J., \& JANZEN, D.H. 1974. Strategies in herhivory by mammals: the role of plant secondary compounds. American Naturalist 108: 269-289.

FURSTENBURG, D. 1991. Die invloed van tamniene in plante op die voedingsekologie van kameelperde Giraffa kamelopardalis. M.Sc thesis. University of Pretoria.

FURSTENBURG, D. \& VAN HOVEN. W. 1992. Condensed tannin as anti-defoliate agent against browsing by giraffe in the Kruger National Park. Comparative Biochemistn and Physiology $101 \mathrm{~A}$. 2. $381-385$.

HAGERMAN, A. 1977. Radial diffusion method for determining tannin in plant extracts. Journal of Chemical Ecolog! 13:437-449. 
KEENEY, D.R. 1982. Nitrogen. In A.L. Page, R.H. Miller \& D.R Keeney, Methods of soil analysis, Part 2. American Society of Agronomy, Wisconsin.

LUNDBERG, P. \& ASTROM. M. 1990. Low nutritive quality as a defense against optimally foraging herbivores. American Naturalist 135: 547-562.

MILEWSKI, A.V., YOUNG, T.P. \& MADDEN, D. 1991. Thorns as induced defences: experimental evidence. Oecologia 86: 70-75.

OWEN-SMITH, N. \& COOPER, S.M. 1987. Palatability of woody plants to browsing ruminants in a South African savanna. Ecology 68: $319-331$.

PRICE, M.L. \& BUTLER. L.G. 1977. The prussian blue assay for polyphenols. Joumal of Agriculture and Food Chemistry 25: 1268-1273.

PORTER. L.W., HRSITCH, J. \& CHAN, C. 1986. The conversion of procyanidins and prodelphinidins to cyanidin and delphinidin. Phytochemistry 25: 223-230.

REICHARDT, P.B., BRYANT, J.P., CLAUSEN, T.P. \& WIELAND. G.D. 1984. Defense of winter-dormant Alaska paper birch against snowshoe hares. Oecologia 65: 58-69.
RHOADES D.F. \& CATES R.G. 1975. Toward a general theory of plant antiherbivore chemistry. Recent Advances in Plant Phytochemistry 10. 168-213.

SIEGEL, S. \& CASTELLAN, N.J. 1989. Nonparamerric statistics. McGraw-Hill, New York.

SWAIN, T. 1979. Tannins and lignins. In G.A. Rosenthal, \& D.H. Janzen. Herbivores: their interactions with secondary plant metabolites: 657-682. Academic Press. New York.

TEAGUE, W.R. 1989a. Patterns of defoliation of Acacia karroo by goats and changes in tannin levels and in vitro digestibility following defoliation. Joumal of the Grassland Society of Southem Africa 6: $230-235$.

TEAGUE. W.R. 1989b. The response of Acacia karroo plants to defoliation of the upper or lower canopy. Joumal of the Grassland Sociery of Southern Africa 4: 225-229.

VAN HOVEN, W. 1984. Trees' secret waming system against browsers. Custos 13: 11-17.

YOUNG, T.P. 1987. Increased thorn length in Acacia drepanolobiuman induced response to browsing. Oecologia $71: 436-438$. 